\title{
1 Erratum zu: Agile Toolbox von A bis Z
}

\section{Erratum zu:}

3 Kapitel 6 In: S. Hofert, Agiler führen,

4 https://doi.org/10.1007/978-3-658-18561-9_6

5 In Kapitel 6 wurde ein Link angegeben, der keinen Zusammenhang mit dem im Kapitel behandelten Thema hatte. Wir haben den Link nun entfernt.

Die korrigierte Version des Kapitels ist verfügbar unter https://doi.org/10.1007/978-3-658-18561-9_6 